\title{
Traumatized Construction of Male and Female Identities in Virginia Woolf's The Waves
}

Leila Baradaran Jamili, Ziba Roshanzamir*

Department of English Language and Literature, Faculty of Postgraduate Department of English Language and Literature, Boroujerd, Islamic Azad University, Boroujerd Branch, Iran

Corresponding Author: Ziba Roshanzamir, E-mail: zibaroshanzamir@gmail.com

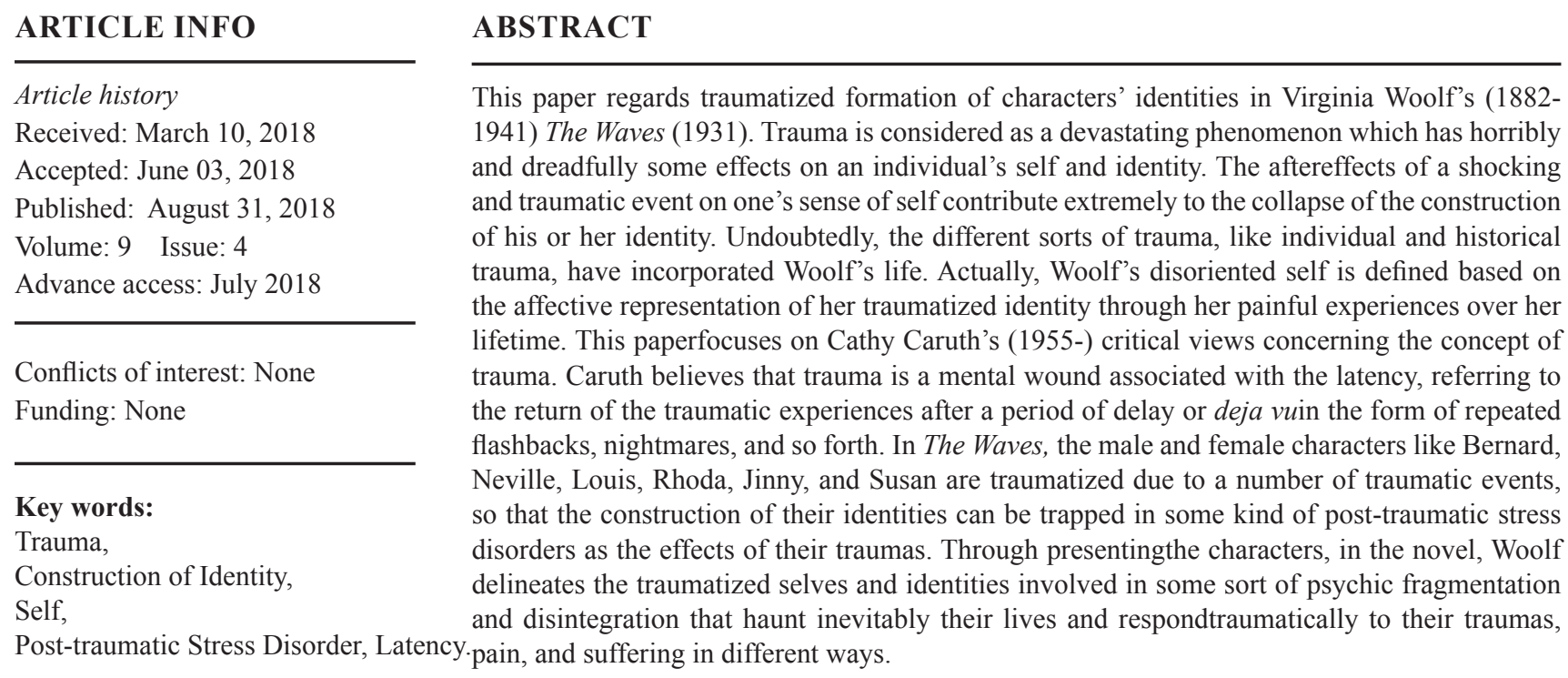

\section{INTRODUCTION}

Self stems from a person's mind. It, however, does not mean that they are the same. Self is what an individual privately experiences of herself or himself. This self has to appear in social relations and acts as an actor playing a part or a role on social stage. Identity signifies 'who one is' and is a criterion of distinguishing oneself from others in a systematic interaction. Despite the fact that self and identity are two different issues they are interchangeable. Thus, the reflexive behavior is the base of knowing the self. In addition, self contributes to the consciousness of one's own self-definition or identity. Self and identity can be affected through the processes of being established or deployed by various notions like language, gender, sex, racism, ethic, religion, environmental interaction and so on. If one's identity and self are disorientated by one or some of the above mentioned notions, they cannot control the meanings and attributes which are very necessary to sustain or maintain the sense of self.

Trauma is one of the most significant factors which has severe and strong impression on the processes of constructing self and identity. Trauma has affected all aspects of one's life tremendously that more importantly, identity is one of them. Experiencing trauma in the form of family violence, race-based oppression, child abuse, natural disasters, rape, etc. can disconnect the traumatized subject from his or her identity and its outcomes are extremely disruptive to his or her life. In this regard, Nigel Hunt claims that " $[\mathrm{t}]$ he relationship between self and identity is central to our understanding of the response to trauma, and links with the social constructions that help to build notions of self-identity" (2010, p. 130).

Regarding such an idea, the relationship between self and identity is understood due to the kind of responses to trauma and is determined through the interaction with social systems in which the concepts of establishing self-conception and self-identity are influential in constructing identity, on the whole. Therefore, responses to trauma which are indicative of changes that occur in the individual's self and identity and reveal that those notions and concepts used for forming identity act in an abnormal way. In this paper, the construction of traumatized identities of male and female in Virginia Woolf's The Waves $(W)$ is analyzed. Woolf tries to present delicately the different sorts of traumas through her male and female characters in the novel. Although, they seem as normal individuals, each one is inflicted with trauma differently. In some of her novels sings of trauma can be understood; for instance, in The Voyage Out, Mrs. Dalloway, To the Lighthouse, Orlando, The Years, Between the 
Acts, and so on. Every novel deals with trauma in different way, but one common thing is comprehensible that is the suppressed femininity as Woolf's leitmotif. For this purpose, the researchers exploit Cathy Caruth's critical debates as the main trauma critic and other trauma theorists for proving theirtheories at best.

\section{MATERIALS AND METHODS}

Cathy Caruth's (1955-) critical theories regardingtraumaare the fundamental discussion of this paper. Trauma stems from the Greek 'traumatikos' that means 'wound' or 'a bodily injury'. First, it was scrutinized in psychoanalytic domain in the late nineteenth century by three researchers' studies: Jean Martin Charcot (1825-1893), Sigmund Freud (1856-1939), and Pierre Janet (1859-1947). Charcot, the French neurologist, was the first figure who studied the subject. These thinkers concentrated their researches on the cause of 'hysteria' as a syndrome in their societies at that special time. Freud later reconsidered Charcot's ideas concerning hysteria as the result of traumatic experiences. Catherine Clément quotes Freud's discoveries of hysteria as "the great clinical secret: hysteria is the result of sexual shock, obsessional neurosis is the result of pleasure which is later transformed into a feeling of guilt" (p. 41-42). What Freud defines as hysteria refers to neurotic disorders whichemerge from sexual experiences obtained before puberty or before the age of maturity.

Based on such an idea trauma engenders a wound or a crisis by which the traumatized subjects cannot normally define or delineate themselves as they are. This type of trauma, in general, is considered as individual trauma. Such trauma as an external force filtrates their psyches and mind to the end that it "splits the mind, lodging itself in a part of the mind that cannot be assimilated" (ibid, p. 200). From this perspective, trauma, in fact, raptures the traumatized's mind so that the mind is not able to completely understand or realize what happened, what happens, or what will happen in the future relating to his or her shattered self. Because self and mind are cooperative with each other strongly. A traumatic event is defined by the nature and essence of the event, by its impressions and influences on subjects, individuals, groups, and by the individuals' and groups' responses to that event. In this regard, the American Psychiatric Association (1987) explains traumatic events as following:

a psychologically distressing event that is outside the range of usual human experience [...] would be markedly distressing to almost anyone, and is usually experienced with intense fear, terror, and helplessness [...] either a serious threat to one's life or physical integrity, a serious threat to harm to one's children, spouse, or other close relatives or friends; sudden destruction of one's home or community; or seeing another person who has recently been, or is being seriously injured or killed as a result of an accident or physical violence. Traumatic events include natural disasters (eg. Floods, earthquakes), accidental disasters (e.g.,m car accidents with serious physical injury, airplane crashes, large fires, collapse of physical structures), and deliberately caused events (e.g. bombing, torture, death campus). (Qtd. in Ursano et al,p. 22)

Based on the events which were mentioned above the effects on people, communities, and societies are both physical and psychological, both in short and long time. By reference to the above mentioned events one common influence can be recognized as terror which is badly emergent response and reaction to traumas. Caruth defines trauma like this:

[i]n its general definition, trauma is described as the response to an unexpected or overwhelming violent event or events that are not fully grasped as they occur, but return later in repeated flashbacks, nightmares, and other repetitive phenomena. (1996: 91)

From Caruth's perfective, trauma is a response or reaction to an unexpected sudden aggressive event or events that cannot completely be realized or understood when they happen or come up, but they are known by their repetitious return through something like a book, scenes, film, or dreams (nightmares) and so on.

Respecting the influence of trauma and aftereffects of traumatic events in the form of responses and reactions, Suzette Henke and David Eberly (2007), the critics who have submitted some critical essays about the effects of trauma on Virginia Woolf's life and her literary career and work, assert that:

[i]n response to the shock of trauma, the brain, stability to integrate experience falls apart. The consequences of this breakdown are physical as well as mental, affecting not only basic biological responses, but also the psychological processes upon which our sense of personal identity is established. (p. 7)

They illustrate that the disorder and chaos emerged from trauma, involving the brain structure function and its mental ability which are the responses of shocking experiences (trauma), leading to both physical and psychological breakdowns. Therefore, the psychological breakdown is interwoven inextricably with the construction of identity. The true sense of self and identity through psychological responses to traumas is associated with fragmentary recognition and image of self-identity defining operationally a criterion and providing the ground for the traumatized identity.

Another kind of trauma called historical trauma refers to a specific event such as war, racial and ethnic aggression and violence which can undertake a transformation into a generalized and symbolized instance of human suffering. Post-traumatic stress disorders regarded as diagnoses of some dissociative disorders have been realized in terms of a number of violent occurrences. Infact, post-traumatic stress disorders are a kindof response to a traumatic event like being a witness to a battle or experiencing the harsh situation of a war, like World Wars, whichcan result in traumatic symptoms that are defined bused on Caruth's explanation like this: "[P] ost-Traumatic stress Disorder (PTSD), which included the symptoms of what had previously been called shellshock, combat stress, delayed stress syndrome, and traumatic nurosis, and referred to responses to both human and natural catastrophes," (1996: P,21).Based on what Caruth stated it can be understood that human catastrophe like war can leadto 
haunting, overwhelming power, and historical trauma that traumatize thoseexperiencing and witnessing it.

In twentieth century two significant World Wars occurred and their disastrous effects were "beyond one's own personal experiences" (Hunt 2010, p. 113). Hunt believes that historical traumas are not compared to individual experiences, or individuals who lived through those particular events were not able to match their own personal experiences with experienced disasters emerged from those two important and traumatic wars.

\section{DISCUSSION AND FINDINGS}

What happened to Woolf, during her life, left an unpleasant mark upon her self-concept, and identity. The sense of guilt, shame, anger, and repressed femininity could never prevent her from being a great and eminent writer. She draws aesthetically on her personal and cultural traumas in her novel, so thatshe can find an emphatic listener to her wounds. She involves the readers to be her addressee in order that her physical and psychological wounds can be cured. In The Waves she cunningly and wisely portrays the construction of the female and male characters' identities as if they are the survivors of the trauma-induced chaos and disturbance.

Woolf seeks to depict the characters' traumatic responses, especially in the character of Rhoda and Louis who sufferfrom the effects of post-traumatic stress disorder. In the novel, the female characters, like Jinny, pave the way for psychiatric acknowledgments of post-traumatic stress disorder with which they are afflicted. Woolf's feminist sense is tickled by delineating three female characters vis-a-vis three male characters. Feeling and understanding the pervasive presence of trauma in the lives of women at the time of Woolf, she reveals the response to the shock of traumas in the women or females differently. However, even the male characters are regarded as the traumatized ones.

\section{The Traumatized Construction of Male Identities in The Waves}

Woolf hasexperienced the trauma of World War I and World War II. The collapse of Woolf's identity into fear, especially by her being confronted with the Great War of 1914-18 (The first World War), is quite tangible in her writings;"'[d]uring that period, England's socio-political control over India was complete" (Baradaran Jamili, p. 274). Historically speaking, Woolf hasexperienced England's situation throughout the Great War that Britain had a huge and ruling empire in India. In The Waves, accordingly, there is a character named Percival. He was one of the friends of the group who soon died in India when his horse stumbled during a race. He went to India for military service as QiuxiaLi says: "[h]e is the representative of imperialism" (2001, p. 79). That is to say, he is regarded as an image of British Empire. Woolf puts him as an absent and voiceless character, so that readers can imagine him. In fact, through Percival, Woolf depicts trauma of war and imperialism which led up to "the history of a trauma, can only take place through the listening of another" (Caruth 1995 , p.11).Caruth comes to believe that a trauma can be re- peated through describing it to a listener. Similarly, Woolf by writing The Waves tends to investigate the male and female traumatized identities through delineating and repeating their traumas at different times on various occasions in the hope that readers might be her listeners. Eric Warner comes to think about this idea that Woolf changes her strategy with regard to depicting the characters of her novels.

In The Waves, since characters both males and females have traumatized construction of identities, they "have no characters but characteristics which differentiate them from one another, and which hold true throughout the work" (Warner 1987, p. 47). In Warner's thoughts, the characters are different from each other by their 'characteristics', and their differences are shown in the novel. Accordingly, the relevant evidence regarding Warner's view is the same as Woolf's The Diary of Virginia Woolf (Woolf's diaries are five Volumes, D1, D2, D3, D4, D5), one entry in the early of spring in 1930: "what I now think (about The Waves) is that I can give in a very few strokes the essentials of a person's character. It should be done boldly, almost as a caricature" (D3, p. 300). As a matter of fact, Woolf highlights the essential and specific dimensions or facets of her characters' attitudes and characteristics which construct their personalities and identities, respectively, and she wants to visualize them as truly as they are by a tinge of exaggeration like a caricaturist. For instance, Bernard who is introduced as a 'maker of phrase' and notes anything in his notebook is traumatized by being separated from his friends, in particular, from Percival who went to India and left him alone.

In the fourth section of the story, when Percival wants to go to India, a farewell party is held in London. For this purpose, the six characters come together in an inn. Each one becomes very excited by visiting the other especially by visiting Percival because they have not met each other since their graduation from high school. In this case Bernard says:

I wish, after this somnolence to sparkle, many-faceted under the light of my friend's faces. I have been traversing the sunless territory of non-identity. A strange land I have had one moment of enormous peace. This perhaps is happiness. I think of people to whom I could say things: Louis, Neville, Susan, Jinny and Rhoda. With them I am many sided. They retrieve me from darkness. We shall meet tonight. Thank Heaven. Thank Heaven, I need not to be alone. We shell dine together. We shall say good-bye to Percival, who goes to India. Yet they drum me alive. They brush off these vapors. I begin to be impatient of solitude. Oh, to toss them off and be active. I am to dine with my friends tonight. I am Bernard, myself. ( $W$, p. 84$)$

Obviously, Bernard suffers from being alone and a feeling of non-identity. On the other hand, he feels joyful and happy by being with his friends. Because he feels a sense of identity with them. Bernard can forget his sadness and loneliness when he is with them. Thus, he thanks God for being with them to "dine together." Bernard is not traumatized physically but mentally. That is to say, Bernard has a psychic disorder presented in his identity as he himself confesses that he lives in "a territory of non-identity" ( $W$, p. 84$)$. In fact, Bernard's post-traumatic stress disorder is because 
of his loneliness repeatedly narrated throughout the novel. Caruth describes post-traumatic stress-disorder in this way:

[t]his [psychic disorder] has culminated in the study of post-traumatic stress disorder, or PTSD, which describes an overwhelming experience of sudden or catastrophic events in which the response to the event occurs in the often uncontrolled, repetitive appearance of hallucinations and other intrusive phenomenon. (1996, pp. 67-68)

The effects of a traumatic experience or event can return in the repetitious forms of agonizing and uncontrolled representation of that phenomenon. These states are the same as post-traumatic stress-disorder due to the traumatic or disastrous event. Concerning Bernard's traumatized identity his post-traumatic stress-disorder is the "repetitive appearance of his feeling of being alone" (ibid, p. 68).

As he says "I begin to be impatient of solitude" ( $W$, p. 84$)$. Because Bernard feels psychologically alone and he is tired of this feeling; moreover, he "preserves negative self-knowledge entirely in sensible terms" (Caruth 1996: 85). Based on Caruth's opinion, Bernard has a negative understanding of himself and of his identity reasonably, or he has a negative image of himself truly. He is aware of his traumatized identity. Bernard "was to collapse incommensurable levels of happenings and thought" (Kaplan 2005, p. 26). Repeating and recalling so often his trauma of being alone, Bernard tends to shatter his incomprehensible traumatic scattered intrusive thoughts. Woolf in her diary in 1929 expresses her feelings of her loneliness:

[h] ere is something to fight: when I wake early I say to myself, fight. If I could catch the feeling, I would: the feeling of the singing of the real world, as one is driven by loneliness \& silence from the habitual world; the sense that comes to me of being bound on an adventure. (D3, p. 260)

By expressingthese sentences, Woolf is engulfed by the unpleasant feelings of loneliness and silence and she wants to fight with them. Furthermore, when Bernard understands that Percival is dead he says: "only that I need silence, and to be alone and to go out, and to say one hour to consider what happened to my world, what death has done to my world" ( $W$, p. 110). When he becomes aware of Percival's death he needs to be alone to ponder over this sorrow and sadness and to find a way to overcome his suffering. Although he hates being alone, he now needs to be alone. Because Percival's death is his trauma as well. He loses his leader and hero as he mentions it in the story, and he thinks that by the death of Percival the chain of their friendship is broken and he is condemned to suffer from this rapture, chaos, and loneliness forever.

Neville, who is in love with Percival, admires him as an ideal figure. While waiting for Percival at the farewell party, Neville confesses his love of him: "I came early; I came quickly and directly, here, to sit by the person whom I love" ( $W$, p. 93). In other words, it is a sort of trauma or individual trauma for them. Likewise, Neville, has the feeling "that it might be removed by some force" (Ryan 2013, p. 122). Death is some force which removes those passions and feelings he had toward Percival:
He is dead, said Neville. He fell. His horse tripped. He was thrown. The sails of the world have swung round and caught me on the head. All is over. The lights of the world have gone out. There stands the tree which I cannot pass. This is the truth. This is the fact. ( $W$, p. 109)

Neville is inflicted with the trauma of Percival's death. He thinks that the world ended up, and "[i]n the wake of traumatic loss, embraces melancholic isolation" (Henke 2007, p. 137). In Henke's idea, in view of his traumatic loss (Percival's death), he finds himself alone and isolated, and he confronts the truth of his friend's death and flashbacks of his post-traumatic stress disorders such as a dead body "with his throat cut" was foundunder the tree ( $W$, p. 15$)$. For clarifying Neville's post-traumatic stress-disorder and his traumatized construction of identity owing to Percival's death, Caruth's view can be supportive: "[t]o be traumatized is precisely to be possessed by an image or event" (1995, p. 21). Caruth proposes that being traumatized is exactly because of experiencing a traumatic event. Neville is traumatized first by observing the dead body under the apple tree when he was young, then by losing his love and his hope. Thus, his identity is traumatized due to these events.

As Caruth says " $[\mathrm{t}]$ he pathology consists, in the structure of its experience or reception: the event is not assimilated or experienced fully at the time, but only belatedly in its repeated possession of the one who experiences it" (ibid). Caruth suggests that the traumatized victim due to traumatic pathology fails to understand or realize the event at the moment of its occurrence and he or she comes to experience it 'belatedly' or by the nature of latency of trauma. Similarly, Neville who experiences a traumatic event and "falls victim to traumatic pathology by watching the dead man and above that by the news of Percival's death suffers from belated consequence of the traumatic experiences by the very repetitive structure (repeated possession) of them" (Marder2006, p. 2). It is realized that Woolf's novel, The Waves, is complicated because of challenging of identity and self-notions in terms of phenomenon of trauma. In fact, she wants to address "her self-awareness and identity" (Rine2013, p. 163). That is, she tends to increase her self-cognition by challenging identity notion. Therefore, she chooses "the doubtful identity of the menacing characters" (Cixous2011, p. 30).

Woolf deals with abnormal or traumatized identity to threaten the characters and makes them feel trapped in their small world. Since Woolf "endlessly seeks her own identity" (Forrester 2015, p. 13), she was in the quest of constructingher own personality because she was herself the victim of trauma in her own life and has the traumatized identity as well. In a letter, in early 1912, to Molly McCarthy (18821953), the British writer and a member of Bloomsbury Group, Woolf in The Letters of Virginia Woolf (Woolf's letters are six volumes, $L 1, L 2, L 3, L 4, L 5, L G$ ), describes her traumas in this way: "[b]ut in my heart I always expect to be floated over all crises, when the moment comes, and landed heaven knows where!" ( $L 1$, p. 492). She talks about her crises and her haunting traumas and she points to the moment at which the trauma returns or repeats and encompasses her.

Louis's identity is traumatized completely different from Bernard's and Neville's identities with an eye to his Austra- 
lian origin. It is concluded that he is a colonized individual, being far from his real home (Australia), and is attached to England's system with reference to his utterances regarding his "handicap of his Australian origins" and his alienation as a colonized one (Henke 2007, p. 139). It is evident that he is afflicted with the historical trauma. As it is said before, by historical trauma one is traumatized by shock, terror, and strong anxiety. The best example of the historical trauma can be the trauma of being colonized. In this case, "trauma theory has argued for broad common sense in the response to massive violence" (Kimayeret al. 2014, p. 303). Based on what was mentioned, trauma theory has a view to things that people share with each other like a massacre of inhabitants. Thus, the survivors will be traumatized. In this regard, Louis's national or collective identity is traumatized:

[y]et I am not included. If I speak imitating their accent, they prick their cars, waiting for me to speak again, in order that they may place me -if I come from Canada or Australia, I, who desire above all things to be taken to the arms with love, an alien, external. ( $W$, p. 67)

Louis's confessed statements respecting his origin in terms of his Australian accent indicate that he suffers and explores the crisis of his identity. Louis calls himself alien and other (external). He desires to be loved and to be regarded by the English. Louis's individual trauma is connected strongly to historical trauma. In this case, Caruth asserts that "we could say that the traumatic nature of history means that events are only historical to the extent that they implicate others. And it is the suffering of other's traumas" (1996, p. 18). Louis lives in the British society and can imitate English accent, but he is not considered as a real English man, and thinks that he is other and alien. It is based on his historical trauma or colonization and it includes his subsequent suffering such as his traumatized construction of identity.

Woolf herself suffers from historical trauma. She is the survivor of war, trauma of World War I, World War II. According to Patrick Duggan, "[t]he impact of which [trauma] is felt within the nerves and the mind of the survivor" (p. 44). Duggan's belief in the mental and nervous effects of trauma on the survivor is associated with Woolf's psychological trauma of war, so that she and Leonard (her husband) thought of suicide and it was said in her diary in May of 1940:

[i]t began (here) with 8 o'clock wireless announcing, as I lay asleep, the invasion of Holland \& Belgium. Churchill exhorting all men to stand together [...]. So my little moment of peace comes in a yawning hollow. But though L. [Leonard] says he has petrol in the garage for suicide shd. Hitler win, we go on. (D5, p. 284)

No wonder, Woolf's and Leonard's identities are traumatized by war trauma or historical trauma, so that they were going to commit suicide. In fact, Woolf refers to the Second World War by which German forces (Hitler) invaded Holland, Belgium and Luxembourg on 10 May 1940. Therefore, her identity was traumatized by being direct witness to the bombards of London by German invasion and their disastrous and traumatic consequences that were "in the collective psyche" (Bratlett 1995, p. 287). Collective psyche or 'collective unconscious' coined by Carl Gustav Jung (1875-1961) in 1916 referring to structures of unconscious mind which are shared among beings of the same species. It is like collective identity which surrounds human being. By the same token, colonization and its outcomes as well as war trauma and historical trauma threaten collective psyche.

\section{The Traumatized Construction of Female Identities in The Waves}

In The Waves, Woolf depicts the three female characters, Rhoda, Jinny, and Susan, in terms of their identities with a feminist's eye to their position, and this reveals that Woolf, as a writer, finds herself different from common people: "[t] he streets are crowded with people quite at their ease; \& the shops blazoning unshaded lights. Yet it is depressing too. We have stretched our minds to consider something universal at any rate" (D1,p. 217-18). Woolf has an exact view to the world and something that separates her from others is her universal perception. No wonder, she concentrates her mind on the female characters in a more precise way.

Rhoda who suffers from isolation, dissociation, and annihilation, "[h]er perceptions are clouded by a pervasive nihilism that precludes the construction of meaning" (Henke 2007 , p. 130). Metaphorically speaking, she realizes herself outside the center of a circle that she draws and moves in the direction that she takes more distance. Terrifying metaphors of annihilation is constructed by Rhoda. Caruth's perspectives in the case of Rhoda is emphatic: "[t]rauma is not simply an effect of destruction but also, fundamentally, an enigma of survival" (1996, p. 58). As she suggests, trauma is a mysterious concept that might serve to be thenotion of survival instead of destruction.

To put emphasis on Rhoda's traumatized identity and on recognizing her being but a different being outside the center of being, Mark S. Micale and Paul Lerner (2001) point out that "trauma turns out to be not an event per se but rather an event in the mind of an individual or the life of a community" (p. 36). They claim that trauma is not defined merely as an event; rather, it takes place in the mind of traumatized one or it involves a community. Relating to Rhoda no traumatic event occurs to her in the novel, but her traumatized mind and her belonging to the community of women, who are traumatized by the community of men, are comprehensible. In a similar way, Woolf in A Room of One's Own $(R O)$ refers to the world in which the narrator is furious at being kept out of the library at Oxbridge and it "has been cursed by a woman" (RO,p. 13). She becomes annoyed by being precluded from having access to the library and she, therefore, curses it.

In June 1923, Woolf clearly mentions imposing predicaments for women, " $[\mathrm{t}]$ he truth is I'm being pushed up, but many people are saying that I shant last, \& perhaps I shant. So I return to my old feeling of my existence, which indeed it is" ( $D$ 2,p. 249). Unlike Rhoda, Woolf was going to be marginalized by the society but she returned to her real feelings and to the center of being of the world. Obviously, Rhoda's traumatized mind contributes to her traumatized identity and to "repressive practices performing analysis of narratives of human rights violations" (Feldman 2004, p. 5). It indicates that systems and norms defined in terms of human rights of the society regarding women's community are repressive 
and oppressive. Thus, Rhoda's human rights are defined based on these violent norms in the male-centered society and consequently her identity is traumatized.

The construction of Jinny's identity is defined based on her narcissistic personality. For instance, Jinny has "relations with the physical and social environment" (Simon 2004, p. 65). In fact, Jinny get involved in the physical and social relations with her surroundings. She is a narcissist who is willing to draw others' attention and needs to be addressed and regarded. The best reason for her narcissist thoughts can be found in these statements in the novel: "[a]11 is exact, prepared. My hair is swept in one curve. My lips are precisely red. I am ready now to join men and women on the stairs, my peers. I pass them, exposed to their gaze, as they are to mine" (W,p. 73). Jinny prepares herself for being admired by others who gaze at her, and she apparently seeks others' admiration and attention.

Narcissism is a sort of trauma that affects one's personality and identity, respectively. ConstaintineSedikides and others assert that "[t]he Diagnostic and Statistical Manual of Mental Disorders (DSM-IV); American Psychiatric Association, (1994) classified narcissism as a personality disorder that distorts several areas of psychological functioning" (p. 105). Probably, it is a traumatic response to psychic disorders. Based on the fourth edition of the above mentioned book in which the classification of mental disorders and diseases are the large-scale symptoms of post-traumatic stress disorders such as narcissism: "[n] arcissists are highly self-focused and egocentric, think of themselves in extraordinarily positive ways, have persistent needs for attention and admiration, and have recurrent fantasies of power, success, and fame" (ibid). Likewise, Jinny as a traumatized person, who is narcissist, has a positive view regarding herself and seeks attention and admiration. She only focuses on her appearance "to celebrate sexuality more than anything else" (Baradaran Jamili 2006, p. 285). She believes that Jinny takes pleasure in exposing her physical body and sexuality because she wants to present herself as far as she can. Jinny's traumatized self is related to "the social world in fundamentally different ways than the normal self" (Sedikides et al 2002, p. 106). Indeed, her traumatized self is interconnectedmorewith the social life.

In the novel, she clearly expresses the post-traumatic stress disorder of her psyche, self, and identity by pointing to the heyday of her narcissistic self: "I do not attach myself to one person in particular, but you will find that if I raise my arm, some figure at once breaks off and will come. And that man is a judge, and that man is a millionaire" ( $W$, p. 70). She has much self-confidence in herself to attract men toward herself even by a hint. She deals with others through "certain trivial or eccentric ways" (Zhang 2012, p. 32).

She cannot perceive her traumatized identity since she is unable to recognize the life-threading and intrusive pleasure which she takes in her appearance and others' admiration. This reflects her low self-esteem. Her traumatized identity due to her narcissism emerges from her low self-esteem. In this case, Woolf, in a letter to Robert Calvery Trevely- an, the English poet and translator who was very close to Bloomsbury Group, on 29 December 1922, writes, “[e]verybody is combed and clipped into their nice, portly, respectable waistcoats and flounces - that, to me, is the heart of the mischief - this conspiracy to mispresent the human soul in the interests of respectability" (L2, p. 301).

Woolf refers to those people who only concentrate on their appearance in the hope that they can attract others' attention, admiration, and respectability, like Jinny who "represents the moment when eccentric behavior becomes identity" (Koppen2009, p. 69). Jinny presents a sort of odd behavior which identifies her as a traumatized person with the traumatized identity. Surprisingly enough, Susan, another female character, expresses Jinny's traumatized identity because of her narcissism: "I do not want, as Jinny wants, to be admired. I do not want people, when I come in, to look up with admiration" ( $W$, p. 52). Susan directly mentions Jinny's traumatized personality and identity.

In the opening section of the novel when the characters are studying in the boarding school, Elevoden, Susan confronts a scene which has a bad effect on her and traumatizes her: "I saw her kiss him. I raised my head from my flower-pot and looked through a chink in the hedge. I saw her kiss him. I saw him, Jinny and Louis kissing. Now I will wrap my agony inside my pocket-handkerchief [...] and die there" (W,p. 40). Susan is traumatized by Jinny and Louis's kiss and, through the novel, she repeats it. Susan is imprisoned between the world of love and hate and it results into the "disorder of self" (Cerulo1997, p. 386). She repeats her paradoxical feelings; she is torn between the world of loving and the world of hating, so that she cannot distinguish her real sense from having these conflicting and contradictory emotions. By remembering her trauma even when she was living her rural life with her father, in fact, she was seeking "to locate identity in a category which can mark off as fixed and certain" (Woodward 2004, p. 42). In The Waves, Susan reminds readers once again that "I sit with my sewing by the table. I think of Jinny; I look at the quivering in the dark garden and think," "They dance in London. Jinny Kisses Louis" (W,p. 50). Caruth's idea is supportive concerning Susan's reaction to the event (the kiss) by the "repetitive appearance of hallucinations" (1996, p. 57). Susan suffers from hallucinations caused by her traumatic experience. Her ambivalent feelings, which are responses to her trauma, are like Woolf's conflicting emotions toward her abusers, George and Gerald.

Woolf in her book, The Second Common Reader(CR), points out clearly the conflicting feelings of love and hatred: "there is always a demon in us who whispers, I hate, I love, and we cannot silence him. Indeed, it is precisely because we hate and we love in relation that we find the presence of another person intolerable" ( $C R$, p. 154). Woolf clarifies this sort of feeling as a destructive emotion concerned with being bothered by another person. Woolf also remembers the positive memory and feeling concerning her half-brother, George Duckworth. In other words, she is traumatized as a victim of him and psychologically speaking, being trapped in this kind of feeling like rage and sympathy, or love and hate. 


\section{CONCLUSION}

In many of Woolf's works either fictional or non-fictional, one can trace a trajectory from imposing pain, terrors, and scenes that are trauma-related. As a case in point, TheVoyage Out and The Years depict their characters' vulnerability, Rachel and Rose, owing to their childhood sexual traumas, respectively. It reveals that the construction of Woolf's characters' identities is influenced by any kind of trauma. Notwithstanding the fact that, at the time of Woolf, trauma was not known as today it is. Getting involved in one's self-conception in a number of traumatic incidents; he or she cannot make an appropriate relationship with others in a community.

Exactly enough, the male and female characters of The Waves are traumatized and victimized, so that they can lose the sense of meaning and are obsessed with abnormal and strange ways in order to attach themselves to others in the society and appear as normal as possible. Likewise, Woolf, as a traumatized subject with the traumatized identity, experiencing some sorts of traumas, endeavors to portray the characters' traumatized identities so as to come to terms with her own traumas. As amatter of fact, Woolf's The Waves functions as a means to create a chaotic world in which the characters have conflicting emotions and feelings and are characterized by symptoms of emptiness, loneliness, and so on. Nonetheless, they attempt to be speaking subjects to relate themselves to their traumatized identities.

It is believed that Woolf wrote The Waves to connect herself to her dear brother's death, Thobywhodied of typhoid fever, and her other traumas. All in all, she represents her character's post-traumatic stress disorders as traumatic responses to their traumas. Utilizing Caruth's critical views in the novel, the researchers strive to demonstrate what affects traumatically the construction of the characters' identities and makes their identities traumatized.

\section{REFERENCES}

Baradaran Jamili, L. (2006). Virginia Woolf: Traveling, Travel Writing and Travel Fictions. BerlinFü UP.

Bratlett, FC. (1995). Remembering: A Social Study in Experimental and Social Psychology. Cambridge: Cambridge UP.

Caruth, C. (1995). (ed. and transl.). Trauma: Explorations in Memory. Baltimore: The Johns Hopkins UP.

-----.(1996). Unclaimed Experience: Trauma, Narrative, and History. London: The Johns Hopkins UP,

Cerulo, KA. (1997). Identity construction: New Issues, New Directions.Annual Reviews Social. Rutgers University, New Brunwick, New Jersey, 385-409.

Cixous, H. (2011). Volleys of Humanity: Essays 1972-2009. Ed. Eric, Precnowtiz. Edinburgh: Edinburgh UP.

Clement, C (ed). (1986). The Newly Born Woman. Ed. Catherine Clement Minneapolis: Minnesota UP.

Duggan, P. (2007). Feeling Performance, Remembering Trauma.Platform, 2 (2), 44-50.

Feldman, A. (2004). Memory Theaters, Virtual Witnessing, And The Trauma. Aesthetic.Biographical Research Center Conference, 27 (1), 5-10. http://muse.jhu.edu. MUSEproject.
Forrester, V. (2015). Virginia Woolf: a portrait. Transl. Gladding, Jody. New York: Columbia UP.

Henke, S A. and D Eberly (eds). (2007). Virginia Woolf and Trauma: Embodied Texts. New York: Pace UP.

Hunt, NC. (2010). Memory, War and Trauma. Cambridge: Cambridge UP.

Kaplan, AE. 2005. Trauma Culture: The Politics of Terror and Loss in Media and Literature. New Jersey: Butgers UP.

Kimayer, LJ et al. (2014). Rethinking Historical Trauma. Transcultural Psychiatry, 51(3), 229-319.

Koppen, R.S. Virginia, Fashion and Literary Modernity. Edinburge: Edinburge UP, 2009.

Li, Q. (2001). The Absent Presence: A study of Percival in The Waves. English Language and Literature Studies, 1 (1), 79-84.

Marder, E. (2006). Trauma and Literary Studies: Some Enabling Questions. Reading on, 1(1), 1-4.

Micale, MS. and P.Lerner (eds.). (2001). Traumatic Pasts: History, Psychiatry, and Trauma in the Modern Age, 1870-1930. Cambridge: Cambridge UP.

Rine, A. (2013). Irigaray, Incarnation and Contemporary Women's Fiction. London: Bloomsbury Publishing.

Ryan, D. (2013). Virginia Woolf and The Materiality of Theory: Sex, Animal, Life. Croydon: Edinburgh UP.

Sedikides, C et al. (2002). Self and Identity: Personal. Social. And Symbolic. Eds. Yoshihisa, Kashima, et al. New Jersey: Lawrence Erlbaum Associate.

Simon, B. (2004). Identity in Modern Society A Social Psychological Perspective. Oxford: Blackwell,

Ursano, RJ et al (eds.). (2006). Individual and Community Responses and Trauma and Disaster: The Structure of Human Chaos. New York: Cambridge UP.

Van der Wiel, R. (2014). Literary Aesthetics of Trauma: Virginia Woolf and Jeanette Winterson. London: Palgrave Macmillan.

Warner, E. (1987). Virginia Woolf: The Waves. New York: Cambridge UP.

Woodward, Kath (ed.). (2004). Questioning Identity: Gender, Class, and Ethnicity. London: Routledge.

Woolf, V. (2006). The Waves. Ed. Mark, Hussey. London: Harcourt.

--. (1977). A Room of One's Own. London: Grafton.

-----. (1984). The Diary of Virginia Woolf. Vol. 5: 1936-1941.

Ed. Anne Olivier Bell. Florida: Harcourt P.

----. (1978). The Diary of Virginia Woolf. Vol.2: 1920-1924. Ed. Anne Olivier Bell, Florida: Harcourt P.

-----. (1980). The Diary of Virginia Woolf. Vol.3: 1925-1930. Ed. Anne Olivier Bell. Florida: Harcourt P.

-----. (1976). The Letters of Virginia Woolf. Vol. 2: 19121922. Eds. Nigel Nicolson and Joanne Trautmann. New York: Harcourt brace Jovanvich.

-----. (1975). The Letters of Virginia Woolf. Vol.1: 19881912. Eds. Nigel Nicolson and Joanne Trautmann. New York: Harcourt Brace Joranovich.

-----. (1948). The Second Common Reader. Second Series. London: Hogarth p.

Zhang, L. (2012). Hysteria and Femininity: A Tentative Investigation into aVictorian and Edwardian Myth.Cambridge Studies, 7(3), 30-36. 